\title{
ANALISIS STRATEGI BERSAING PASAR KAGET UNTUK MEMENANGKAN PERSAINGAN
}

\author{
Purwanto $^{1,2}$, Anaconda Bangkara ${ }^{2}$ \\ ${ }^{1}$ Faculty of Economic and Business, Padjajaran University, Bandung, Indonesia \\ ${ }^{2}$ Faculty of Business, President University, Bekasi, Indonesia
}

\begin{abstract}
The problem companies are becoming increasingly complex and competitive business be increased very sharply, as a result of changes in the business environment in the era of globalization. Companies must be able to adapt to the environment in order to survive in the midst of these conditions. For that management is required to manage the organization in a better and more professional in controlling the activities of the company. Business "shock market" Cikarang, Jababeka, Bekasi as a collection of merchants who sell various products to lower middle class should immediately anticipate and prepare for making new business strategies to survive and thrive in the future. The study has the purpose of analyzing the external and internal business environment, identifying, evaluating business strategies and finding alternative strategies for the future that can be implemented " shock market." External business environment will be analyzed with descriptive qualitative method involving shared business environment (economic, political, ecological and technological), Porter's competitive forces, the forces of the trigger and the key success factors. The results showed that the manager should earnestly follow external analysis results such as politics, economics and ecology as well as industrial environments (competition among members of the industry, the threat of new entrants, threat of substitute products, buyer powerful and strong supplier)
\end{abstract}

Keywords : market shock, the external business environment, the strength of competition Porter

\section{Pendahuluan}

\subsection{Latar Belakang Masalah}

Perkembangan bisnis di era globalisasi saat ini mengakibatkan kompetisi antar perusahaan semakin hebat. Tantangan yang dihadapi setiap perusahaan terus bertambah dan kompleks seiring tuntutan dari dalam maupun luar. Pasar tradisional termasuk pasar kaget kini kian tereduksi oleh hadirnya pusat perbelanjaan modern di Indonesia paska reformasi 1998 hingga kini.

Eksistensi pasar modern di Indonesia mengalami perkembangan yang sangat pesat. Menurut data yang diperoleh dari Euromonitor (2004), hypermarket merupakan peritel dengan tingkat pertumbuhan paling tinggi (25\%), koperasi (14,2\%), minimarket convenience stores (12,5\%), independent grocers $(8,5 \%)$, dan supermarket (3,5\%). Selain mengalami pertumbuhan dari sisi jumlah dan angka penjualan, peritel modern mengalami pertumbuhan pangsa pasar sebesar $2,4 \%$ per tahun terhadap pasar tradisional. Berdasarkan survey AC Nielsen (2006) menunjukkan bahwa pangsa pasar dari pasar modern meningkat sebesar $11,8 \%$ selama lima tahun terakhir. Jika pangsa pasar dari pasar modern pada tahun 2001 adalah $24,8 \%$ maka pangsa pasar tersebut menjadi 32,4\% tahun 2005. Hal ini berarti bahwa dalam periode 2001 - 2006, sebanyak 11,8\% konsumen ritel Indonesia telah meninggalkan pasar tradisional dan beralih ke pasar modern. 
Persoalan eksistensi pasar tradisional pada era globalisasi sekarang ini memang menarik disoroti, terlebih peran yang diembannya sebagai bisnis ritel tradisional. Adanya liberalisasi bisnis ritel tidak terlepas dari liberalisasi ekonomi. Nilai investasi bisnis ritel modern di tahun 2006 sebesar Rp 50,8 triliun dan tahun 2008 meningkat menjadi Rp 58,5 triliun. Hal tersebut berlanjut di tahun 2010 dimana bisnis ritel modern tumbuh 12\% dan tahun 2012 diperkirakan ritel modern akan tumbuh 13\% 15\%. Kondisi ini tentunya sangat kontras dengan kondisi perekonomian yang dihadapi pasar tradisional.

Menurut data yang dihimpun dari Kemendag tahun 2011 menyebutkan pasar tradisional mengalami pertumbuhan minus $8,1 \%$ setiap tahunnya. Tingkat profitabilitas pasar tradisional juga mengalami penyusutan secara masif semenjak ritel mengalami liberalisasi pada tahun 2000. Tercatat bahwa profitabilitas pasar tradisional di kawasan Jabodetabek pada tahun 2001 mengalami penyusutan hingga 40\% dan pada 2011 lalu pasar tradisional mengalami penyusutan mencapai 60\%. Kondisi serupa juga berlaku di berbagai wilayah Indonesia lainnya yang rata-rata mencapai $70-80 \%$ tiap tahunnya. Oleh karena itulah, sinyalemen bahwa perekonomian nasional tidak berpihak kepada rakyat memang benar adanya. Matinya pasar tradisional sebagai arena ekonomi mikro bagi rakyat oleh hadirnya ritel modern yang dikomandoi oleh swasta asing yang berkolaborasi dengan swasta nasional menandakan bahwa terjadi praktik neokolonialisme dalam konteks perekonomian di Indonesia.

Di kota Jababeka, Cikarang, Bekasi dengan jumlah lebih dari 10 ribu perumahan, merupakan pasar yang potensial bagi peritel nasional maupun peritel asing. Memang banyaknya jumlah penduduk merupakan faktor utama berhasil tidaknya pasar ritel. "Pasar kaget" yang diselenggarakan sejak tahun 2011 dan dilaksanakan setiap akhir minggu dan diberi nama "Festival Belanja dan Kuliner Plaza JB" sebagai salah satu pasar ritel simbol perekonomian rakyat. Nilai utilitas atau nilai guna pasar kaget sangat urgen bagi masyarakat bawah, karena terdapat puluhan ribu orang rakyat kecil (pedagang) yang menggantungkan biaya hidupnya, sumber penghidupannya. Pasar ini berada di bawah pengelolaan manajemen PT. Tsann Kuen Property Development Indonesia dan beralamat di Jl. Niaga Raya Kav. 1, Jababeka Cikarang 17550. Sebagai gambaran, pasar kaget atau pasar festival digelar setiap akhir minggu di halaman parkir Plaza JB yang diikuti sekitar 151 pedagang internal (tenant) dan pedagang eksternal. Pedagang internal berasal dari peserta yang setiap harinya membuka kios atau toko di dalam supermarket Plaza JB, sedangkan pedagang eksternal berasal dari luar yang telah lolos seleksi. Jenis produk yang dijual dikelompokkan ke dalam kuliner atau makanan serta non kuliner yang berupa produk asesoris, pakaian, boneka dan sejenisnya.

Supermarket di Cikarang tumbuh dengan pesat dan mengindikasikan munculnya berbagai masalah di pasar tradisional umumnya dan pasar kaget khususnya. Indikasi ini terlihat ketika konsumen dan pelanggan berlari meninggalkan pasar kaget dan beralih ke berbagai supermarket. Mengantisipasi perkembangan beralihnya masyarakat ke supermarket, diperlukan peningkatan tuntutan masyarakat yang menginginkan pelayanan pasar yang lebih profesional dan sekaligus mengantisipasi perkembangan atau persaingan perdagangan eceran (retail business) yang semakin tajam dan semakin ketat di masa yang akan datang, maka dituntut melakukan upaya pembenahan untuk mengubah/memperbaiki citra (image) pasar kaget yang terkesan negatif untuk kemudian tampil dalam performa baru menyangkut manajemen/restrukturisasi, sumber daya manusia, sumber dana, kualitas pelayanan dan kuantitas komoditas yang dijual sesuai dengan tuntutan masyarakat. Ditambah lagi di bawah manajemen PT. Jababeka juga menyelenggarakan pasar pagi sejak sekitar setahun yang lalu dan diberi nama Pasar Bersih Cikarang.

Kondisi tersebut mengharuskan pihak manajemen dapat mengelola organisasinya secara lebih baik dan profesional agar perusahaan (pasar kaget) tetap survival dan tujuan perusahaan yang telah ditetapkan dapat tercapai secara efektif dan efisien, mampu mengevaluasi kejadian dan perubahan 
masa lalu dan mampu bereaksi terhadap perubahan yang sedang terjadi saat ini maupun masa yang akan datang. Pihak manajemen harus introspeksi diri dengan melihat apakah selama ini pedagang telah memahami keinginan konsumen ataukah belum. Apakah persepsi pedagang selama ini sama dengan konsumen ataukah tidak mengenai faktor yang dipertimbangkan konsumen untuk berbelanja di pasar kaget. Selain itu juga perlu diketahui variabel apa yang dipertimbangkan konsumen sehingga memutuskan berbelanja di supermarket atau cenderung di pasar kaget.

\subsection{Rumusan dan Pembatasan Masalah}

Pasar kaget di dekat pemukiman telah memberikan dampak positif diantaranya mampu memberikan pelayanan bagi kebutuhan warga; menyediakan kebutuhan sehari-hari, memberikan peluang usaha, kesempatan kerja serta mendorong pengembangan suatu wilayah, yang pada akhirnya jika kesejahteraan dan pendapatan ekonomi meningkat akan berpengaruh pada perbaikan kualitas masyarakat. Khusus pasar festival, penyelenggaraan setiap akhir pekan bertujuan untuk menarik pembeli dan menambah pelanggan untuk berbelanja di tenda/lapak serta memasuki Plaza JB yang akhir-akhir ini mulai sepi pengunjung. Hal inilah yang mendasari pemikiran manajemen PT. Tsann Kuen Property Development Indonesia agar pasar festival harus banyak pengunjung dan dapat memenangkan persaingan dengan kompetitor lainnya termasuk Pasar Bersih Cikarang dan ritel lainnya.

Berdasarkan latar belakang di atas, permasalahan yang akan dibahas pada penelitian ini adalah

"Analisis Strategi Bersaing Pasar Kaget untuk Memenangkan Persaingan (Studi Kasus Pasar Festival Belanja dan Kuliner Plaza JB, Jababeka, Cikarang) ." Hal-hal yang akan dibahas dalam tulisan ini adalah strategi manajemen untuk mempertahankan pelanggan serta dapat meningkatkan jumlah konsumen sehingga pengguna atau penyewa pasar kaget meningkat.

Analisa permasalahan akan dibatasi dalam ruang lingkup sebagai berikut:

a. Lokasi penelitian pasar kaget akan dibatasi di Pasar Festival Belanja dan Kuliner Plaza JB wilayah kota Jababeka, Cikarang, Bekasi yang diselenggarakan sejak tahun tahun 2011.

b. Pemakaian data internal, antara lain: jumlah pengguna/penyewa, biaya sewa, jenis produk yang dijual, jumlah pengunjung, jumlah karyawan yang diambil sejak tahun $2011 \mathrm{ke}$ atas. Data kompetitor akan diambil melalui PT. Jababeka, Tbk dan hanya kompetitor yang masih aktif dan sehat.

c. Data struktur organisasi, survey kepuasan pelanggan dan observasi langsung di lapangan saat pasar kaget digelar.

\section{Tujuan dan Manfaat Penelitian}

\subsection{Tujuan Penelitian}

Tujuan yang ingin dicapai dari penelitian adalah:

a. Menyediakan informasi tentang kebutuhan konsumen/pelanggan, khususnya di Kota Jababeka, Cikarang serta peluang Pasar Festival Belanja dan Kuliner Plaza JB untuk memasok produkproduknya sehingga manajemen dapat mengambil keputusan apakah bisnis yang dijalankan selama ini masih memiliki prospek menjanjikan atau tidak di tahun mendatang.

b. Mengidentifikasi para pesaing yang memasok produk sejenis dan melakukan pemantauan terhadap produk yang dihasilkan sebagai bahan evaluasi.

c. Mengidentifikasi dan mengevaluasi sistem yang telah dijalankan di internal perusahaan dan dampak bagi konsumen/pelanggan. 
d. Menghasilkan sistem dan metoda yang lebih baik untuk direkomendasikan ke manajemen agar pasar kaget dapat bersaing dengan pasar modern sehingga meningkatkan jumlah omzet.

\subsection{Manfaat Penelitian}

Penelitian ini diharapkan dapat memberikan manfaat bagi pihak-pihak yang terkait diantaranya sebagai berikut:

a. Bagi pihak manajemen, diharapkan penelitian ini dapat memberikan alternatif dalam rangka perbaikan dan penyempurnaan proses di internal untuk mengoptimalkan jumlah omzet serta rencana strategi menghadapi pesaing.

b. Memberikan kesempatan besar bagi penulis untuk menambah dan memperluas pengetahuan dalam penyusunan strategi yang diterapkan di bisnis pasar kaget.

c. Bagi pihak lain, dapat meningkatkan pengetahuan serta wawasan dalam melihat peluang di pasar dan strategi yang akan dipakai organisasi demi memenangkan persaingan.

\section{Tinjauan Pustaka}

\subsection{Manajemen Stratejik}

Manajemen stratejik merupakan kumpulan keputusan dan tindakan yang menghasilkan formulasi dan implementasi rencana, yang didesain untuk mencapai tujuan suatu perusahaan. Karena manajemen stratejik mencakup pengambilan keputusan jangka panjang, berorientasi masa yang akan datang dan rumit, serta memerlukan sumber-sumber daya yang diperlukan, maka partisipasi manajemen puncak adalah penting.

Manajemen stratejik adalah proses tiga deretan bertingkat yang meliputi perencanaan tingkat korporat, usaha dan fungsional, serta personil pendukung. Pada tingkat yang lebih bawah, aktivitasaktivitas stratejik ditunjukkan lebih khusus, sempit, jangka pendek, dan berorientasi tindakan dengan resiko yang lebih rendah, akan tetapi kesempatan yang lebih kecil untuk pengaruh yang dramatis.

\subsection{Lingkungan Eksternal (External Environment)}

Ada banyak faktor eksternal yang mempengaruhi pilihan arah dan tindakan suatu perusahaan dan akhirnya struktur organisasi serta proses internalnya. Faktor-faktor ini yang dinamakan lingkungan eksternal, dapat dibagi menjadi sub-kategori yang saling berkaitan: faktor-faktor dalam lingkungan jauh (remote), faktor-faktor dalam lingkungan industri dan faktor-faktor dalam lingkungan operasional. Secara bersama-sama, faktor-faktor ini merupakan landasan peluang dan ancaman yang dihadapi perusahaan dalam lingkungan bersaingnya. Lingkungan jauh terdiri dari faktor-faktor yang bersumber dari luar, seperti: ekonomi, sosial, politik, teknologi dan faktor ekologi.

Faktor ekonomi berkaitan dengan sifat dan arah sistem ekonomi tempat suatu perusahaan beroperasi. Baik di tingkat nasional maupun internasional, perusahaan harus mempertimbangkan ketersediaan kredit secara umum, tingkat penghasilan yang dapat dibelanjakan (disposable income), serta kecenderungan belanja masyarakat (propensity to spend). Suku bunga primer, laju inflasi serta kecenderungan pertumbuhan PNB merupakan faktor-faktor ekonomi lain yang harus pula dipertimbangkan. Faktor sosial yang mempengaruhi suatu perusahaan adalah kepercayaan, nilai, sikap, opini dan gaya hidup orang-orang di lingkungan eksternal perusahaan, yang berkembang dari pengaruh kultural, ekologi, demografi, agama, pendidikan dan etnik. Faktor politik berkaitan dengan 
Purwanto

Anaconda Bangkara
Jurnal Manajemen Bisnis Indonesia

Vol. 4, Nomor 1, Oct 2016

arah dan stabilitas yang menentukan parameter legal dan regulasi yang membatasi operasi perusahaan. Kendala politik dikenakan atas perusahaan melalui keputusan tentang perdagangan yang adil, undangundang antitrust, program perpajakan, ketentuan upah minimum, kebijakan tentang polusi dan penetapan harga, batas administratif dan banyak lagi tindakan yang dimaksudkan untuk melindungi pekerja, konsumen, masyarakat umum dan lingkungan. Faktor teknologi dapat mempunyai dampak segera dan dramatik atas lingkungan perusahaan. Terobosan teknologi dapat membuka pasar dan produk baru yang canggih atau dapat juga mempersingkat usia fasilitas produksi. Faktor ekologi dalam tahun 1990-an paling menonjol dalam lingkungan jauh seringkali adalah hubungan timbal balik antara bisnis dan ekologi. Istilah ekologi mengacu pada hubungan antara manusia dan makhluk hidup lainnya dengan udara, tanah dan air yang mendukung kehidupan mereka. Ancaman terhadap ekologi pendukung kehidupan kita yang utamanya disebabkan oleh kegiatan manusia dalam suatu masyarakat industrial biasanya dinamakan polusi.

\subsection{Lingkungan Industri (Industry Environment)}

Buku dari guru besar Harvard Michael E. Porter "Competitive Strategy (strategi bersaing)" mendorong konsep lingkungan industri ke permukaan pemikiran strategi dan perencanaan usaha. Inti dari buku tersebut adalah Porter menjelaskan 5 kekuatan yang membentuk kompetisi dalam industri. Kerangka kerja Porter yang didefinisi dengan baik membantu manajer stratejik mengaitkan pengaruh dari faktor-faktor "remote" terhadap akibat yang dihasilkan pada lingkungan operasi perusahan. Menurut Porter, sifat dan tingkat kompetisi dalam suatu industri bergantung pada 5 kekuatan (five competitive forces), yaitu:

1. Ancaman pendatang baru (The threat of new entrants)

2. Daya tawar pelanggan (The bargaining power of customer)

3. Daya tawar pemasok (The bargaining power of supplier)

4. Ancaman produk atau jasa substitusi (The threat of substitute products or services)

5. Persaingan diantara kontestan yang ada (The jockeying among current contestants atau rivalry among existing firms)

Untuk menyusun rancangan strategi menghadapi kekuatan-kekuatan ini dan tumbuh, suatu perusahaan harus memahami bagaimana cara kerja kekuatan-kekuatan tersebut dalam industri dan bagaimana pengaruh mereka terhadap perusahaan dalam situasi tertentu. Intisari formulasi strategi adalah menanggulangi persaingan. Tetapi sering sekali kita memandang persaingan terlalu sempit dan terlalu pesimistik. Tambahan lagi, dalam perjuangan untuk memperoleh bagian pasar (market share), persaingan tidak hanya terjadi di antara sesama peserta persaingan. Persaingan dalam suatu industri berakar pada situasi ekonomi yang mendasarinya, dan kekuatan persaingan yang ada tidak hanya berupa peserta persaingan atau perusahaan yang sudah ada dalam industri tersebut. Pelanggan (pembeli), pemasok, calon pendatang baru, dan produk substitusi (pengganti) semua merupakan "peserta persaingan" yang dapat penting atau aktif bergantung pada industrinya. Kekuatan gabungan dari faktor-faktor ini menentukan potensi laba suatu industri. Persaingan dalam industri dapat tajam seperti ban, kaleng logam dan baja, yang para anggotanya tidak menikmati ROI tinggi, atau sedangsedang saja seperti dalam industri jasa dan peralatan perminyakan, minuman ringan dan kebutuhan kamar mandi, yang para anggotanya masih berpeluang menikmati laba sangat tinggi.

\subsection{Kekuatan-kekuatan Pemicu (Driving Forces)}

Perubahan industri dan kondisi persaingan menyebabkan kekuatan-kekuatan saling menarik atau menekan peserta industri untuk mengubah tindakan mereka. Kekuatan-kekuatan pemicu 
mempunyai pengaruh paling besar dengan berbagai macam perubahan dalam struktur industri dan lingkungan persaingan. Beberapa kekuatan pemicu berasal dari lingkungan makro perusahaan dan beberapa berasal dari dalam industri dan lingkungan persaingan (Thompson \& Strickland III, 2005).

\subsection{Faktor-faktor Kunci Keberhasilan (Key Success Factors)}

Analisis industri termasuk mengidentifikasi faktor-faktor yang berkaitan dengan partisipasi yang berhasil dalam industri tertentu. Penentu kunci keberhasilan dalam suatu industri dapat digunakan untuk mengidentifikasi kekuatan dan kelemahan internal suatu perusahaan. Dengan meneliti pesaing industri, dan juga kebutuhan pelanggan, struktur industri vertikal, saluran distribusi, biaya, hambatan untuk masuk, ketersediaan substitusi dan pemasok, manajer strategi berusaha menentukan apakah kemampuan internal perusahaan sekarang menggambarkan kekuatan atau kelemahan dalam area bersaing yang baru (Thompson \& Strickland III, 2005).

\subsection{Pengertian Pasar dan Pasar Kaget}

Berdasarkan Keputusan Menteri Perindustrian dan Perdagangan Nomor 23/MPP/KEP/1/1998 tentang Lembaga-lembaga Usaha Perdagangan, pasar didefinisikan sebagai tempat bertemunya pihak penjual dan pembeli untuk melaksanakan transaksi dimana proses jual beli terbentuk. Pasar menurut kelas pelayanannya dapat digolongkan menjadi pasar tradisional dan pasar modern, sedangkan menurut sifat pendistribusiannya dapat digolongkan menjadi pasar eceran dan pasar perkulakan/grosir.

Pasar kaget sebagai salah satu bentuk pasar tradisional telah diatur di dalam Peraturan Presiden Republik Indonesia Nomer 112 Tahun 2007 Tentang Penataan dan Pembinaan Pasar Tradisional, Pusat Perbelanjaan dan Toko Modern pada pasal 1 ayat 2; "Pasar Tradisional adalah pasar yang dibangun dan dikelola oleh Pemerintah, Pemerintah Daerah, Swasta, Badan Usaha Milik Negara dan Badan Usaha Milik Daerah termasuk kerja sama dengan swasta dengan tempat usaha berupa toko, kios, los dan tenda yang dimiliki/dikelola oleh pedagang kecil, menengah, swadaya masyarakat atau koperasi dengan usaha skala kecil, modal kecil dan dengan proses jual beli barang dagangan melalui tawar menawar." Dengan demikian, tanpa adanya campur tangan pemerintah atau sebuah badan usaha, maka pengelolaan dan pengendalian pasar tersebut tidak akan optimal.

Dalam lingkup pasar tradisional terdapat 3 (tiga) pelaku utama yang terlibat, dalam aktivitas sehari-hari, yaitu : penjual, pembeli dan pegawai/pejabat dinas pasar (Riasto Widiatmoko, Jurnal Bisnis Strategi, 2006). Selain 3 pelaku utama tersebut terdapat pelaku lain, yaitu : buruh panggul, petugas parkir, petugas kebersihan, preman dan copet. Ciri-ciri pasar tradisional :

a. Dalam pasar tradisional tidak berlaku fungsi-fungsi manajemen : planning, organizing, actuating dan controlling.

b. Tidak ada konsep marketing, yaitu : pembeli adalah raja, terdapat pelayanan penjualan, penentuan harga berdasarkan perhitungan harga pokok ditambah keuntungan tertentu, produk berkualitas, tempat penjualan yang nyaman bagi pembeli, dan lain-lain.

Sedangkan penjual pasar tradisional biasanya mempunyai ciri :

a. Tempat penjualannya kumuh, sempit, tidak nyaman, kotor

b. Penampilan penjualnya tidak menarik

c. Cara menempatkan barang dagangan tanpa konsep marketing.

Adapun pembeli pasar tradisional mempunyai ciri :

a. Rela berdesak-desakan di tempat yang kumuh dan tidak nyaman

b. Tidak peduli dengan lalu-lalang pembeli lainnya 
c. Pembeli pasar tradisional biasanya menguasai dan mengenal pasar tersebut utamanya masalah harga, karena bila tidak tahu, harga komoditas bisa dua atau tiga kali lipat.

Definisi pasar kaget tidak dapat ditemukan dalam peraturan perundangan sehingga secara implisit dapat dinyatakan bahwa pemerintah belum menganggap perlu pengawasan dan pengelolaan jenis pasar tersebut. Sementara itu menurut Kamus Besar Bahasa Indonesia, pasar kaget adalah pasar sesaat yang terjadi ketika terdapat sebuah keramaian atau perayaan. Namun bagi masyarakat Jababeka, Cikarang, sebutan pasar kaget adalah satu jenis pasar tradisional dengan kegiatan pasar yang sifatnya sementara dengan wadah berjualan yang tersedia tidak permanen atau semi permanen dan aktivitasnya hanya untuk hari Sabtu sore dan Minggu pagi.

\subsection{Lokasi Pasar}

Bervariasinya kegiatan yang terjadi dalam pasar serta peran pasar yang penting dalam suatu kota, mengakibatkan pasar membutuhkan lahan dan tempat yang strategis di kota tersebut. Pasar merupakan salah satu komponen pelayanan dari suatu kota, daerah dan wilayah tertentu sehingga akan mengakibatkan kaitan dan pengaruh antar unsur penunjang kegiatan perekonomian kota. Sebuah pasar yang letaknya strategis akan lebih menjamin kelancaran penjualannya daripada yang letaknya di tempat yang kurang strategis. Faktor-faktor keramaian lalu lintas, kemungkinan sebagai tempat pemberhentian orang untuk berbelanja, keadaan penduduk di lingkungan tersebut, keadaan perparkiran kendaraan dan lain-lain merupakan hal-hal yang perlu diperhatikan dalam penentuan lokasi sebuah pasar.

Lokasi dimana pasar itu dibangun akan sangat mempengaruhi minat masyarakat untuk mengunjungi pasar tersebut. Faktor penting yang harus menjadi pertimbangan adalah wilayah perdagangan yang membatasi suatu kota. Pasar sebaiknya dibangun pada wilayah perdagangan yang ramai dan luas. Pasar yang dibangun pada tempat yang tidak ada aktivitas perdagangan sangat sulit diharapkan akan dikunjungi oleh masyarakat. Jarak antara masyarakat yang diperkirakan akan berkunjung sebaiknya juga tidak terlalu jauh dan untuk mencapainya tersedia cukup fasilitas transportasi atau aksesibilitas yang lancar. Beberapa hal yang menjadi jarak yang jauh dirasakan menjadi lebih dekat yaitu adanya jalan dan transportasi, kemudahan untuk parkir, kelengkapan dan kualitas barang-barang yang dijual dan kemudahan untuk mencapai lokasi (tidak macet misalnya).

Jumlah penduduk, pendapatan perkapita, distribusi pendapatan, aglomerasi dan kebijakan pemerintah sangat berpengaruh dalam penentuan lokasi suatu kegiatan (Marsudi Djojodipuro, 1992). Suatu daerah yang memiliki jumlah penduduk banyak merupakan pasar yang perlu dipertimbangkan.

\subsection{Penelitian Terdahulu}

Penelitian terdahulu merupakan hasil dari penelitian-penelitian sebelumnya yang berhubungan dengan penelitian yang akan dilakukan ole duh penulis mengenai pasar kaget. Penelitian-penelitian yang telah dilakukan sebelumnya adalah sebagai berikut :

1. "Keberadaan dan Perkembangan Pasar Kaget Rawajati Jakarta”, Wicak Hardhika, 2010. Hasil penelitiannya sebagai berikut : Potensi perkembangan pasar kaget Rawajati disebabkan karena demand yang selalu meningkat dan supply yang cukup memenuhi. Selain hal tersebut, ada kemudahan pedagang dan pembeli untuk bertransaksi. Perkembangan pasar dinilai oleh sebagian masyarakat akan dapat meningkatkan dan mengembangkan usaha mereka sehingga sebagian masyarakat menginginkan perkembangan. Perkembangan pasar kaget Rawajati akan memberi dampak terhadap lingkungan pasar dan pemukimannya. Lingkungan pasar dan pemukiman 
khususnya di sekitar pasar akan menjadi bertambah kumuh, jalan semakin macet dan semrawut, saluran drainase mampet, sampah bertambah, jalanan becek dan bau tak sedap.

2. "Analisis Faktor-faktor yang Mempengaruhi Pemilihan Lokasi Terhadap Kesuksesan Usaha Jasa (Studi Pada Usaha Jasa Mikro-Kecil di Sekitar Kampus Undip Pleburan),” Azizah Pratiwi, 2010. Hasil penelitiannya sebagai berikut : Pemilihan lokasi usaha yang memperhatikan variabel kedekatan dengan infrastruktur, kedekatan dengan lingkungan bisnis dan biaya lokasi terbukti memberikan pengaruh yang positif dan signifikan terhadap kesuksesan usaha jasa berskala mikro kecil yang berada di sekitar kampus Undip, Pleburan, Semarang.

\section{Metode Penelitian}

\subsection{Metoda Pengumpulan Data}

Pengumpulan data adalah prosedur yang sistematik dan standar untuk memperoleh data yang diperlukan (Moh. Nazir, 1988 : 2011). Dalam penelitian ini metode pengumpulan data adalah dengan cara pengamatan langsung, melakukan wawancara, dan juga menggunakan daftar pertanyaan yang sering disebutkan secara umum dengan nama kuesioner. Pengamatan data dengan observasi langsung atau dengan pengamatan langsung dilakukan dengan cara melihat langsung dan mengamati lokasi kegiatan usaha yang berada di lapangan.

\section{a. Studi pustaka}

Studi kepustakaan dilakukan dengan cara mempelajari berbagai sumber pustaka seperti bukubuku teks, literatur, jurnal, surat kabar dan makalah yang terkait dengan masalah penelitian sebagai bahan yang akan digunakan dalam penulisan.

\section{b. Studi lapangan}

Pengumpulan data dilakukan melalui:

1). Mengamati dan mewawancara (interview) para pejabat pengambil keputusan serta pelaksana di lapangan berupa gambaran atau uraian mengenai strategi yang diterapkan pihak manajemen pasar kaget.

2). Meninjau dan mengamati proses transaksi para penjual dan pembeli untuk memastikan tawar menawar harga dan jumlah maupun kualitas produk yang ada

\subsection{Jenis Data}

\section{a. Data primer}

Data primer dikumpulkan melalui survei primer yang dilakukan melalui pengamatan dan pengukuran langsung (observasi) di lokasi pasar festival dan penyebaran kuesioner kepada pedagang dan pengunjung. Adapun teknik pengumpulan data primer terbagi atas beberapa cara, di antaranya adalah pengamatan visual seluruh lokasi dan aktivitas pasar festival. Teknik kedua yaitu melalui rekaman visual, cara ini bertujuan untuk merekam kondisi aktual dengan mengambil gambar menggunakan foto dalam upaya merekam data-data kondisi lapangan. Teknik ketiga yaitu melalui wawancara, teknik ini mencoba menggali lebih dalam mengenai tanggapan pihak manajemen, pedagang dan pengunjung untuk memperkuat analisa yang dilakukan. Teknik terakhir yaitu melalui kuesioner, teknik ini dilakukan untuk memperoleh informasi permasalahan dan potensi wilayah halaman parkir Plaza JB saat ini serta untuk menggali aspirasi dan preferensi pedagang terhadap perkembangan pasar festival. Dengan 
demikian diharapkan bahwa studi ini dapat dilakukan dengan menggunakan kompilasi data yang didapatkan dari instansi terkait dan masukan dari masyarakat setempat sehingga data yang diperoleh secara keseluruhan menjadi lebih akurat.

\section{b. Data sekunder}

Sumber data dapat digolongkan menjadi sumber informasi internal (organisasional) dan eksternal. Sumber internal merupakan data yang berasal dari database manajemen pasar kaget baik yang berbentuk laporan jumlah lapak, jenis produk, struktur organisasi dan kebijakan perusahaan, denah lokasi, jumlah pedagang dan catatan lainnya yang relevan. Sedangkan data eksternal berasal dari Badan Pusat Statistik (BPS), Website Jababeka, PT. Nielsen Indonesia, Departemen Perindustrian dan Perdagangan (Depperindag) serta data dari buku yang diterbitkan oleh Pemda Kabupaten Bekasi.

\subsection{Teknik Sampling}

Teknik sampling yang digunakan adalah simple random sampling, dalam hal ini semua responden mendapat kesempatan yang sama untuk diambil sampel. Jumlah sampel ditentukan dengan menggunakan rumus Taro Yamane, sebagai berikut :

$$
\begin{array}{rlrl}
N & \text { Dimana : } \\
n=------- & \mathrm{n} & =\text { jumlah sample } \\
N d^{2}+1 & \mathrm{~N} & =\text { jumlah populasi } \\
& \mathrm{d} & =\text { level signifikansi yang diinginkan }
\end{array}
$$

Berdasarkan rumus tersebut, dapat diperoleh rincian jumlah sampel sebagai berikut :

a. Sampel pedagang

Dengan jumlah populasi sebesar 151 pedagang dan menggunakan level signifikansi sebesar $10 \%$, maka diperoleh jumlah sampel sebesar :

$$
\begin{aligned}
& \mathrm{n}=151 /(151 \times(0,1 \times 0,1))+1 \\
& \mathrm{n}=151 / 2,51 \\
& \mathrm{n}=60,16
\end{aligned}
$$

b. Sampel pengunjung

Jumlah populasi pengunjung didapat dari data parkir mobil dan motor selama pasar diselenggarakan dan hasil wawancara dengan petugas keamanan sekitar 4000 orang serta menggunakan level signifikansi sebesar $10 \%$, diperoleh jumlah sampel sebesar :

$$
\begin{aligned}
& \mathrm{n}=4000 /(4000 \times(0,1 \times 0,1))+1 \\
& \mathrm{n}=4000 / 41 \\
& \mathrm{n}=97,56
\end{aligned}
$$

Tabel 4.1. Daftar Jumlah Populasi dan Sampel

\begin{tabular}{|l|c|c|l|}
\hline Kelompok Sampel & Jumlah Populasi & Jumlah Sampel & Keterangan \\
\hline Sampel Pedagang & 151 & 90 & Dibulatkan ke atas \\
\hline Sampel Pengunjung & 4000 & 150 & Dibulatkan ke atas \\
\hline
\end{tabular}

Sumber : Hasil Analisis Peneliti, 2013 


\subsection{Metoda Analisa Data}

Metoda analisa yang digunakan dalam penelitian ini dibagi menjadi dua jenis pendekatan, yaitu

a. Metode kuantitatif, digunakan untuk mengetahui faktor-faktor yang berpengaruh dalam preferensi masyarakat terhadap perkembangan pasar kaget. Metode ini menggunakan data numeric sehingga dapat ditarik suatu kesimpulan analisis.

b. Metode deskriptif kualitatif, yaitu membandingkan teori-teori tentang stratejik manajemen dengan praktek yang sedang diterapkan oleh manajemen untuk menentukan sampai sejauh mana kesenjangan atau kelemahan dan kelebihan strategi organisasi. Apabila terjadi kelemahan atau kesenjangan akan diidentifikasi serta dicari penyebabnya kemudian diberikan pemecahan untuk perbaikan sistem dan prosedur penetapan strategi organisasi yang diteliti.

\section{Analisa dan Pembahasan}

\subsection{Identitas Responden}

Dalam identitas responden ini terdiri dari jenis kelamin, usia, pendidikan dan etnis atau suku asal. Hasil keseluruhan dari data responden ditunjukkan dalam tabel berikut ini.

Tabel 5.1. Identitas Responden

\begin{tabular}{|c|c|c|c|c|}
\hline Jawaban & Jenis Kelamin & Usia (Tahun) & Pendidikan & Etnis/Suku Asa \\
\hline 1 & $55 \quad(61,11 \%)$ & $\begin{array}{ll}9 & (10,00 \%) \\
\end{array}$ & $3(3,33 \%)$ & $36 \quad(40 \%)$ \\
\hline 2 & $35 \quad(38,88 \%)$ & $(43,33 \%)$ & $13(14,44 \%)$ & $23 \quad(25,55 \%)$ \\
\hline 3 & & $37 \quad(41,11 \%)$ & $61 \quad(67,77 \%)$ & $20 \quad(22,22 \%)$ \\
\hline 4 & & $5 \quad(5,55 \%)$ & $7(7,77 \%)$ & $11(12,22 \%)$ \\
\hline 5 & & & $5(5,55 \%)$ & \\
\hline 6 & & & $1(1,11 \%)$ & \\
\hline 7 & & & $0 \quad(0 \%)$ & \\
\hline Total & $90 \quad(100 \%)$ & $90 \quad(100 \%)$ & $90 \quad(100 \%)$ & $90 \quad(100 \%)$ \\
\hline
\end{tabular}

Catatan : Isi nomor jawaban sesuai daftar pertanyaan

Sumber : Diolah oleh Peneliti, 2013

Menurut data jenis kelamin yang didapat selama melakukan survei dengan pemberian kuesioner terhadap 90 pedagang di pasar festival Plaza JB, menunjukkan bahwa jenis kelamin laki-laki lebih banyak dibanding perempuan dalam melakukan usaha atau berdagang. Hal ini terbukti bahwa prosentase laki-laki sebesar $61,11 \%$ atau 55 orang dan prosentase perempuan sebesar $38,88 \%$ atau 35 orang dari total sampel yang diambil. Laki-laki yang merupakan tulang punggung keluarga kelihatan bekerja keras dengan berwiraswasta dengan membuka usaha di setiap akhir minggu. Berdasarkan dari usia selama melakukan survei terbukti bahwa pedagang yang berada di usia $15-<25$ tahun sebesar $10 \%$, usia $25-<35$ tahun sebesar $43,33 \%$, usia $35-<45$ tahun sebesar $41,11 \%$ dan usia $\geq 45$ tahun sebesar $5,55 \%$. Hal ini menunjukkan bahwa usia yang berdagang di pasar festival lebih banyak usia produktif dan terlihat masih dalam taraf belajar untuk mencari peluang usaha. Ditinjau dari segi pendidikan menggambarkan bahwa lulusan SMA/SMK sangat dominan dengan prosentase $67,77 \%$, 
diikuti lulusan SMP sebesar 14,44\%, Diploma 7,77\%, Sarjana 5,55\%, SD 3,33\% dan S2 sebesar 1,11\%. Angka ini memperlihatkan bahwa berdagang di pasar festival tidak menuntut pendidikan yang tinggi namun diperlukan keberanian. Berdasarkan etnis/asal suku menunjukkan bahwa suku Jawa masih paling tinggi sebesar $40 \%$, diikuti Sunda 25,55\%, Sumatera 22,22\% dan lain-lain 12,22\%. Suku Jawa masih banyak di daerah Cikarang terbukti dari hasil survei tersebut. Sedangkan maksud dari suku lain-lain adalah Lombok, Betawi, Kalimantan dan beberapa suku lainnya.

\subsection{Informasi Perdagangan}

Dalam kategori ini dibagi ke dalam lama waktu usaha, jumlah karyawan, komoditas usaha, waktu usaha, besar keuntungan per hari dan biaya sewa tempat per bulan. Ringkasan data tersebut ditunjukkan di bawah ini :

Tabel 5.2. Informasi Perdagangan

\begin{tabular}{|c|c|c|c|c|c|c|}
\hline Jawaban & $\begin{array}{c}\text { Lama } \\
\text { Waktu } \\
\text { Usaha }\end{array}$ & $\begin{array}{c}\text { Jumlah } \\
\text { Karyawan }\end{array}$ & $\begin{array}{l}\text { Komoditas } \\
\text { Usaha }\end{array}$ & $\begin{array}{l}\text { Waktu } \\
\text { Usaha }\end{array}$ & $\begin{array}{c}\text { Keuntungan } \\
\text { Per Hari }\end{array}$ & $\begin{array}{c}\text { Sewa } \\
\text { Tempat } \\
\text { Per Bulan }\end{array}$ \\
\hline 1 & \begin{tabular}{|l|}
28 \\
$(31,11 \%)$
\end{tabular} & $33(36,67 \%)$ & $19(21,11 \%)$ & 12-Jun & $14(15,55 \%)$ & $5(5,55 \%)$ \\
\hline 2 & \begin{tabular}{|l|}
21 \\
$(23,33 \%)$
\end{tabular} & $29(32,22 \%)$ & $41(45,55 \%)$ & 12-Jun & $24(26,66 \%)$ & $3(3,33 \%)$ \\
\hline 3 & $\begin{array}{l}21 \\
(23,33 \%)\end{array}$ & $2(2,22)$ & $13(14,44 \%)$ & 12-Jun & $25(27,77 \%)$ & $\begin{array}{c}73 \\
(81,11 \%)\end{array}$ \\
\hline 4 & \begin{tabular}{|l|}
20 \\
$(22,22 \%)$
\end{tabular} & $2(2,22)$ & $17(18,88 \%)$ & 12-Jun & $14(15,55 \%)$ & $5(5,55 \%)$ \\
\hline 5 & & & & 12-Jun & $13(14,44 \%)$ & $4(4,44 \%)$ \\
\hline Total & $\begin{array}{l}90 \\
(100 \%)\end{array}$ & $90 \quad(100 \%)$ & $90 \quad(100 \%)$ & $\begin{array}{l}90 \\
(100 \%)\end{array}$ & $90(100 \%)$ & $\begin{array}{l}90 \\
(100 \%)\end{array}$ \\
\hline
\end{tabular}

Catatan : Isi nomor jawaban sesuai daftar pertanyaan

Sumber : Diolah oleh Peneliti, 2013

Berlandaskan data di atas dapat dianalisa bahwa lama waktu usaha sebagian besar pedagang masih di bawah satu tahun yang ditunjukkan dengan prosentase sebesar $31,11 \%$, sedangkan pedagang lainnya telah melakukan usahanya di atas satu tahun seiring sejak dibukanya pasar festival sejak 2011. Menurut kategori jumlah karyawan menggambarkan bahwa selama melakukan usaha, para pedagang cenderung melakukan usaha sendiri dengan prosentase hasil survei sebesar 36,67\%, diikuti usaha dengan memiliki karyawan sebagai rekan kerjanya sebanyak 1 sampai 3 orang dengan prosentase $32,22 \%$ dan lainnya memiliki karyawan di atas 3 orang dengan prosentase yang kecil. Berdasarkan jenis komoditas usahanya, paling banyak para pedagang berjualan pakaian dengan prosentase $45,55 \%$ diikuti kuliner $21,11 \%$, diikuti berbagai jenis usaha lain dan asesories. Waktu usaha para pedagang rata-rata dibuka jam 06.00 pagi sampai 12.00 siang. Sedangkan menurut besar keuntungan per hari menjelaskan bahwa rata-rata pendapatan setiap usaha antara Rp 100.000,- sampai $\mathrm{Rp} 400.000,-$, digambarkan pada tabel di atas dengan prosentase berkisar 26,66\% dan 27,77\% selanjutnya pendapatan mereka di bawah Rp 100.000,- atau lebih dari Rp 550.000,- per harinya. Biaya sewa per bulan yang 
harus ditanggung pedagang berada di harga $\mathrm{Rp} 150.000$,- sampai $\mathrm{Rp} 250.000$,- per bulannya. Sedangkan lainnya lebih murah karena mendapat dispensasi dari manajemen.

\subsection{Kondisi Pasar/Infrastruktur}

Tabel 5.3. Kondisi Pasar/Infrastruktur

\begin{tabular}{|c|c|c|c|c|c|c|c|}
\hline Jawaban & $\begin{array}{l}\text { Kondisi } \\
\text { Jalan } \\
\text { Baik }\end{array}$ & $\begin{array}{c}\text { Ketersediaan } \\
\text { Lahan } \\
\text { Parkir }\end{array}$ & $\begin{array}{c}\text { Ketersedia } \\
\text { an Listrik }\end{array}$ & $\begin{array}{c}\text { Ketersedia } \\
\text { an Air }\end{array}$ & $\begin{array}{c}\text { Kondisi } \\
\text { Persampah } \\
\text { an Baik }\end{array}$ & $\begin{array}{c}\text { Luas } \\
\text { Lapak } \\
\text { Yang } \\
\text { Memadai }\end{array}$ & $\begin{array}{c}\text { Kondisi } \\
\text { Keaman } \\
\text { an Yang } \\
\text { Baik } \\
\end{array}$ \\
\hline 1 & $\begin{array}{l}2 \\
(2,22 \%)\end{array}$ & $1(1,11 \%)$ & $\begin{array}{l}21 \\
(23,33 \%)\end{array}$ & $\begin{array}{l}19 \\
(21,11 \%)\end{array}$ & $0(0 \%)$ & $0 \quad(0 \%)$ & $0(0 \%)$ \\
\hline 2 & $\begin{array}{l}9 \\
(10 \%)\end{array}$ & $19(21,11 \%)$ & $48(5$ & $\begin{array}{l}12 \\
(13,33 \%)\end{array}$ & $8(8,88 \%)$ & $\begin{array}{l}22 \\
(24,44 \%)\end{array}$ & $\begin{array}{c}4 \\
(4,44 \%)\end{array}$ \\
\hline 3 & $\begin{array}{l}21 \\
(23,33 \%)\end{array}$ & $25(27,77 \%)$ & $\begin{array}{l}10 \\
(11,11 \%)\end{array}$ & $\begin{array}{l}21 \\
(23,33 \%)\end{array}$ & $\begin{array}{l}19 \\
(21,11 \%)\end{array}$ & $\begin{array}{l}41 \\
(45,55 \%)\end{array}$ & $\begin{array}{l}22 \\
(24,44 \%)\end{array}$ \\
\hline 4 & $\begin{array}{l}49 \\
(54,44 \%)\end{array}$ & $41(45,55 \%)$ & $\begin{array}{l}11 \\
(12,22 \%)\end{array}$ & $36(40 \%)$ & $\begin{array}{l}51 \\
(56,66 \%)\end{array}$ & $\begin{array}{l}26 \\
(28,88 \%)\end{array}$ & $\begin{array}{l}49 \\
(54,44 \%)\end{array}$ \\
\hline 5 & $9(10 \%)$ & $4(4,44 \%)$ & $0(0 \%)$ & $2(2,22 \%)$ & $\begin{array}{l}12 \\
(13,33 \%)\end{array}$ & $\begin{array}{l}1 \\
(1,11 \%)\end{array}$ & $\begin{array}{l}15 \\
(16,66 \%)\end{array}$ \\
\hline Total & $\begin{array}{l}90 \\
(100 \%)\end{array}$ & $90 \quad(100 \%)$ & $\begin{array}{l}90 \\
(100 \%)\end{array}$ & $\begin{array}{l}90 \\
(100 \%)\end{array}$ & $\begin{array}{l}90 \\
(100 \%)\end{array}$ & $\begin{array}{l}90 \\
(100 \%)\end{array}$ & $\begin{array}{l}90 \\
(100 \%)\end{array}$ \\
\hline
\end{tabular}

Catatan : Isi nomor jawaban sesuai daftar pertanyaan

Sumber : Diolah oleh Peneliti, 2013

Berdasarkan tabel di atas memperlihatkan bahwa pedagang merasa puas dengan beberapa fasilitas yang disediakan oleh manajemen pasar festival seperti: kondisi jalan yang baik, ketersediaan lahan parkir, kondisi persampahan, luas lapak yang memadai serta kondisi keamanan yang baik. Ada dua hal yang harus diperbaiki oleh pihak manajemen yaitu ketersediaan listrik dan air karena menurut data di atas, pedagang masih belum puas. 


\subsection{Alasan Memilih Lokasi}

Tabel 5.4 Alasan Memilih Lokasi

\begin{tabular}{|c|c|c|c|c|c|c|c|}
\hline Jawaban & $\begin{array}{c}\text { Tersedianya } \\
\text { Sarana } \\
\text { Transportasi }\end{array}$ & $\begin{array}{c}\text { Biaya } \\
\text { Transpor } \\
\text { tasi } \\
\text { Murah }\end{array}$ & $\begin{array}{l}\text { Harga } \\
\text { Sewa } \\
\text { Tempat } \\
\text { Murah }\end{array}$ & $\begin{array}{l}\text { Jumlah } \\
\text { Pembeli } \\
\text { Banyak }\end{array}$ & $\begin{array}{l}\text { Jumlah } \\
\text { Pesaing } \\
\text { Sedikit }\end{array}$ & $\begin{array}{c}\text { Lokasi } \\
\text { Pasar } \\
\text { Tidak Jauh } \\
\text { dari } \\
\text { Rumah }\end{array}$ & $\begin{array}{c}\text { Tersedianya } \\
\text { Kelengkapan } \\
\text { Peralatan }\end{array}$ \\
\hline 1 & $\mathbf{0}(\mathbf{0 \%})$ & $0(0 \%)$ & $0(0 \%)$ & $0(0 \%)$ & $\begin{array}{l}1 \\
(1,11 \%)\end{array}$ & $2(2,22 \%)$ & $2(2$, \\
\hline 2 & $6(6,66 \%)$ & $\begin{array}{l}11 \\
(12,22 \%)\end{array}$ & $\begin{array}{l}30 \\
(33,33 \%)\end{array}$ & \begin{tabular}{|l|}
8 \\
$(8,88 \%)$ \\
\end{tabular} & $\begin{array}{l}37 \\
(41,11 \%)\end{array}$ & $\begin{array}{l}22 \\
(24,44 \%)\end{array}$ & $16(17,77 \%)$ \\
\hline 3 & $19(21,11 \%)$ & $\begin{array}{l}20 \\
(22,22 \%)\end{array}$ & $\begin{array}{l}31 \\
(34,44 \%)\end{array}$ & $\begin{array}{l}22 \\
(24,44 \% \\
)\end{array}$ & $\begin{array}{l}16 \\
(17,77 \%)\end{array}$ & $\begin{array}{l}15 \\
(16,67 \%)\end{array}$ & $32(35,55 \%)$ \\
\hline 4 & $60(66,67 \%)$ & $\begin{array}{l}58 \\
(64,44 \%)\end{array}$ & $\begin{array}{l}29 \\
(32,22 \%)\end{array}$ & \begin{tabular}{|l|}
58 \\
$(64,44 \%$ \\
)
\end{tabular} & $\begin{array}{l}35 \\
(38,88 \%)\end{array}$ & $\begin{array}{l}48 \\
(53,33 \%)\end{array}$ & $39(43,33 \%)$ \\
\hline 5 & $5(5,55 \%)$ & $1(1,11 \%)$ & $0(0 \%)$ & \begin{tabular}{|l|}
2 \\
$(2,22 \%)$ \\
\end{tabular} & $\begin{array}{l}1 \\
(1,11 \%)\end{array}$ & $3(3,33 \%)$ & $1(1,11 \%)$ \\
\hline Total & $90 \quad(100 \%)$ & $\begin{array}{l}90 \\
(100 \%)\end{array}$ & $\begin{array}{l}90 \\
(100 \%)\end{array}$ & \begin{tabular}{|l|}
90 \\
$(100 \%)$ \\
\end{tabular} & $\begin{array}{l}90 \\
(100 \%)\end{array}$ & $90(100 \%)$ & $90 \quad(100 \%)$ \\
\hline
\end{tabular}

Sumber : Diolah oleh Peneliti, 2013

Tabel di atas menggambarkan bahwa kriteria pedagang dalam memilih lokasi dikarenakan pasar festival dekat dengan sarana transportasi, biaya transportasi yang murah, jumlah pembeli yang banyak, lokasi tidak jauh dari rumah dan tersedianya kelengkapan peralatan. Sedangkan satu hal yang dikeluhkan pedagang karena banyak penjual dengan komoditas barang sama sehingga banyak pesaing.

Sarana transportasi merupakan preferensi utama bagi pedagang dalam pemilihan lokasi. Plaza JB yang terletak di wilayah dekat jalan utama dan perlintasan bagi angkutan kota, bus, kendaraan pribadi serta kendaraan bermotor memudahkan pedagang dalam distribusi dan pengangkutan barang dagangannya. Dalam survei diperoleh angka 66,67\% menunjukkan bahwa responden setuju bahwa sarana transportasi sebagai alasan pemilihan pasar festival sebagai tempat berdagang.

Biaya transportasi murah adalah dasar pedagang untuk pemilihan lokasi. Di samping akses jalan yang mudah, murahnya biaya transportasi baik menggunakan angkutan umum maupun kendaraan pribadi juga menjadi pertimbangan pedagang. Responden menyatakan setuju dengan biaya transportasi murah yang dinyatakan dengan prosentase sebesar 64,44\% atau sekitar 58 dari 90 pedagang.

Harga sewa tempat masih dirasakan memberatkan bagi sebagian pedagang. Alasan ini tidaklah berlebihan jika dibandingkan dengan pendapatan pedagang selama berjualan per bulannya. Responden menyatakan dengan merasa tidak setuju 33,33\% dan biasa atau cukup 33,34\%. Sedangkan pedagang menganggap sewa tempat masih murah jika dibandingkan dengan larisnya dagangan dan tingginya omset yang didapatkan, angka ini ditunjukkan dengan prosentase sebesar 32,22\%.

Jumlah pembeli banyak dijadikan alasan pedagang lebih tertarik memilih pasar festival sebagai tempat berjualan. Hasil observasi menunjukkan bahwa jumlah pengunjung tidak kurang dari 
Purwanto

Anaconda Bangkara
Jurnal Manajemen Bisnis Indonesia

Vol. 4, Nomor 1, Oct 2016

4000 orang per minggu, berasal dari sekitar perumahan dan pemukiman penduduk. Data ini diperkuat melalui penjelasan petugas parkir dan petugas keamanan yang selalu berada di lapangan. Responden setuju dengan jumlah ini dan ditunjukkan dengan prosentase sebesar 64,44\%.

Pedagang tidak setuju dengan pernyataan jumlah pesaing sedikit, kenyataan ini diperlihatkan dengan angka tidak setuju sebesar 41,11\%, diikuti dengan menjawab biasa sebesar 17,77\%. Banyak pedagang yang menjual barang dengan jenis sama seperti pakaian, asesoris, mainan, dompet dan lainlain. Namun di antara pedagang tidak mengeluh dengan banyaknya pesaing terutama bagian kuliner atau makanan, terbukti semua makanan hampir dipastikan habis sebelum jam 12.00 WIB. Ungkapan ini dibuktikan dengan prosentase sebesar 38,88\%.

Lokasi pasar tidak jauh dari rumah sebagai alasan utama sebagian pedagang. Banyak pedagang berasal dari lingkungan perumahan atau daerah pemukiman setempat. Angka ini ditunjukkan dengan prosentase setuju sebesar 53,33\%, meskipun beberapa pedagang tidak berasal daerah setempat atau dirasakan jauh dari tempat tinggal. Perasaan ini dituangkan dalam angka sebesar $24,44 \%$ dan diikuti tanggapan biasa sebesar 24,44\%.

Tersedianya kelengkapan peralatan juga menjadi salah satu alasan berdagang di tempat ini. Tersedianya lapak, tenda, terpal, tempat sampah dan kelengkapan lainnya memberikan kontribusi untuk menarik sejumlah pedagang. Kenyataan ini ditunjukkan dengan prosentase setuju dan sangat setuju sebesar $35,55 \%$ dan $43,33 \%$.

\subsection{Analisis Lingkungan Internal}

Analisis dan penilaian lingkungan (environment assessment) pasar festival Plaza JB lebih rumit harus menilai beberapa lingkungan secara bersamaan. Sekumpulan faktor-faktor lingkungan eksternal, lingkungan industri, kekuatan pemicu dan faktor kunci keberhasilan mempengaruhi pemilihan arah dan tindakan suatu perusahaan, akhirnya berdampak pada struktur organisasi dan proses internalnya. Akurasi analisis metoda kuantitatif dan kualitatif dalam peramalan masih diperdebatkan dan kebanyakan riset masih memenangkan model kuantitatif, tetapi perbedaan hasil yang diperoleh kedua metoda ini seringkali tipis saja. Beberapa model analisis yang dipakai untuk meramal faktor-faktor di atas adalah analisis SWOT. Secara keseluruhan analisis ini menyoroti peranan sentral bahwa identifikasi kekuatan-kekuatan dan kelemahan-kelemahan berperan dalam pencarian strategi yang efektif oleh perusahaan. Peluang dan ancaman eksternal secara sistematis dibandingkan dengan kekuatan dan kelemahan internal dalam pendekatan yang terstruktur. Walaupun analisis SWOT menyoroti peranan dari analisis internal dalam mengidentifikasi strategi-strategi yang sehat, analisis SWOT tidak menjelaskan bagaimana pengelola mengidentifikasi kekuatan-kekuatan dan kelemahankelemahan internal.

\subsection{Analisis Lingkungan Eksternal}

Ada beberapa faktor eksternal yang saling berinteraksi antara satu dengan lainnya sehingga mempengaruhi proses atau operasi keputusan strategi suatu pasar. Analisis dan diagnosis lingkungan eksternal memberikan waktu kepada para penyusun strategi untuk mengantisipasi kesempatankesempatan dan merencanakan tanggapan atau reaksi terhadap lingkungan tersebut.

Faktor-faktor yang bersumber dari luar seperti: ekonomi, politik, ekologi dan teknologi biasanya tidak berhubungan dengan situasi operasional perusahaan. Lingkungan ini memberikan kesempatan-kesempatan, ancaman-ancaman dan kendala bagi perusahaan, akan tetapi jarang suatu perusahaan tunggal mempunyai pengaruh timbal balik yang berarti. 
Purwanto

Anaconda Bangkara
Jurnal Manajemen Bisnis Indonesia

Vol. 4, Nomor 1, Oct 2016

\subsubsection{Faktor ekonomi}

Glueck menyatakan bahwa keadaan ekonomi pada saat sekarang dan dalam masa depan dapat mempengaruhi nasib baik dan strategi perusahaan. Berbagai faktor ekonomi yang spesifik harus dianalisis perusahaan meliputi: tingkat siklus bisnis, trend inflasi atau deflasi harga barang dan jasa, kebijakan moneter, tarip bunga dan devaluasi atau revaluasi serta kebijakan perpajakan. Setiap elemen faktor ekonomi tersebut dapat membantu atau merintangi pencapaian tujuan dan kesuksesan atau kegagalan perusahaan (Supriyono, 1993, Manajemen Strategi dan Kebijakan Bisnis).

\subsubsection{Faktor politik}

Faktor-faktor politik menentukan parameter legal dan regulasi yang membatasi operasional pasar tradisional maupun ritel dalam merumuskan strategi. Salah satu isu politik yang hangat pada masyarakat konsumen adalah perlindungan konsumen, ketenagakerjaan, perlindungan dan pelestarian lingkungan hidup serta peraturan-peraturan pemerintah. Undang-undang tenaga kerja dianggap oleh dunia usaha pada umumnya sangat berpihak kepada pekerja tidak segera diubah pemerintah. Titik lemah materi undang-undang tersebut masih sering dipakai sebagai celah Serikat Pekerja dalam memenuhi tuntutan hak karyawan daripada melaksanakan kewajiban semestinya. Ketentuan upah minimum yang harus dinaikkan setiap tahun merupakan beban tersendiri bagi perusahaan karena tidak diikuti peningkatan etos kerja beberapa karyawan. Kelonggaran peraturan bagi buruh untuk mengajukan protes dan demonstrasi turut serta melengkapi hambatan kemajuan perusahaan.

\subsubsection{Faktor ekologi}

Ancaman terhadap ekologi yang utama disebabkan oleh kegiatan manusia dalam suatu masyarakat industrial biasa dinamakan polusi. Sebagai penyebab utama polusi ekologis, bisnis sekarang memikul tanggung jawab untuk meniadakan hasil samping limbah atau sampah dan membersihkan kembali lingkungan yang telah tercemar.

\subsection{Analisis Lingkungan Industri}

Sifat dan derajat persaingan dalam suatu industri bergantung pada lima kekuatan atau faktor, yaitu: ancaman pendatang baru, ancaman produk pengganti atau substitusi (jika ada), daya tawar-menawar pembeli (pelanggan), daya tawar-menawar pemasok dan pertarungan di antara para anggota industri (peserta persaingan). Tindakan untuk menyusun rancangan strategi menghadapi kekuatan-kekuatan yang tumbuh, suatu perusahaan harus memahami bagaimana cara kerja kekuatan-kekuatan tersebut dalam industri dan bagaimana pengaruh mereka terhadap perusahaan dalam situasi tertentu (Thompson \& Strickland III, 2005). 


\subsubsection{Ancaman pendatang baru}

Munculnya pasar-pasar tradisional dan pasar festival yang baru mengakibatkan jumlah pelanggan semakin berkurang. Hal ini diakibatkan karena banyaknya perumahan-perumahan baru yang menyelenggarakan pasar kaget di internal perumahan maupun di sekitar kawasan.

\subsubsection{Ancaman produk pengganti}

Dengan menetapkan batas harga tertinggi (ceiling price), produk substitusi membatasi potensi suatu industri. Jika industri tidak mampu meningkatkan kualitas produk atau mendiferensiasikannya, laba dan pertumbuhan industri dapat terancam. Semakin atraktif saling tukar harga-kinerja yang dijanjikan produk substitusi, makin berat tekanan yang dialami potensi laba industri.

Di tengah-tengah maraknya pasar ritel seperti Alfamart dan Indomart yang memberikan jenis produk sejenis dengan harga yang relatif sama akan membuat ancaman bagi pasar festival Plaza JB.

\subsubsection{Pembeli yang kuat}

Posisi pembeli atau pelanggan akan kuat apabila membeli dalam jumlah besar dan mengingat komponen yang dibeli sangat penting dan biaya yang dikeluarkan tinggi maka pelanggan sangat selektif dalam memilih pemasok. Pembeli pasar festival memiliki daya tawar yang tinggi sebab banyak penjual menyediakan jenis produk yang sejenis sehingga kesempatan memilih dan menawar barang lebih kuat serta mulai bermunculannya pasar tradisional di sekitarnya.

\subsubsection{Pemasok yang kuat}

Berkenaan dengan jumlah pasar yang semakin banyak mengakibatkan penjual memiliki daya tawar yang cukup untuk memilih apakah akan berjualan di pasar festival Plaza JB atau tidak.

\subsubsection{Persaingan di antara anggota industri}

Persaingan di kalangan pasar festival sangat besar karena letak dan jarak dengan rirel maupun pasar tradisional lainnya tidak terlalu jauh. 


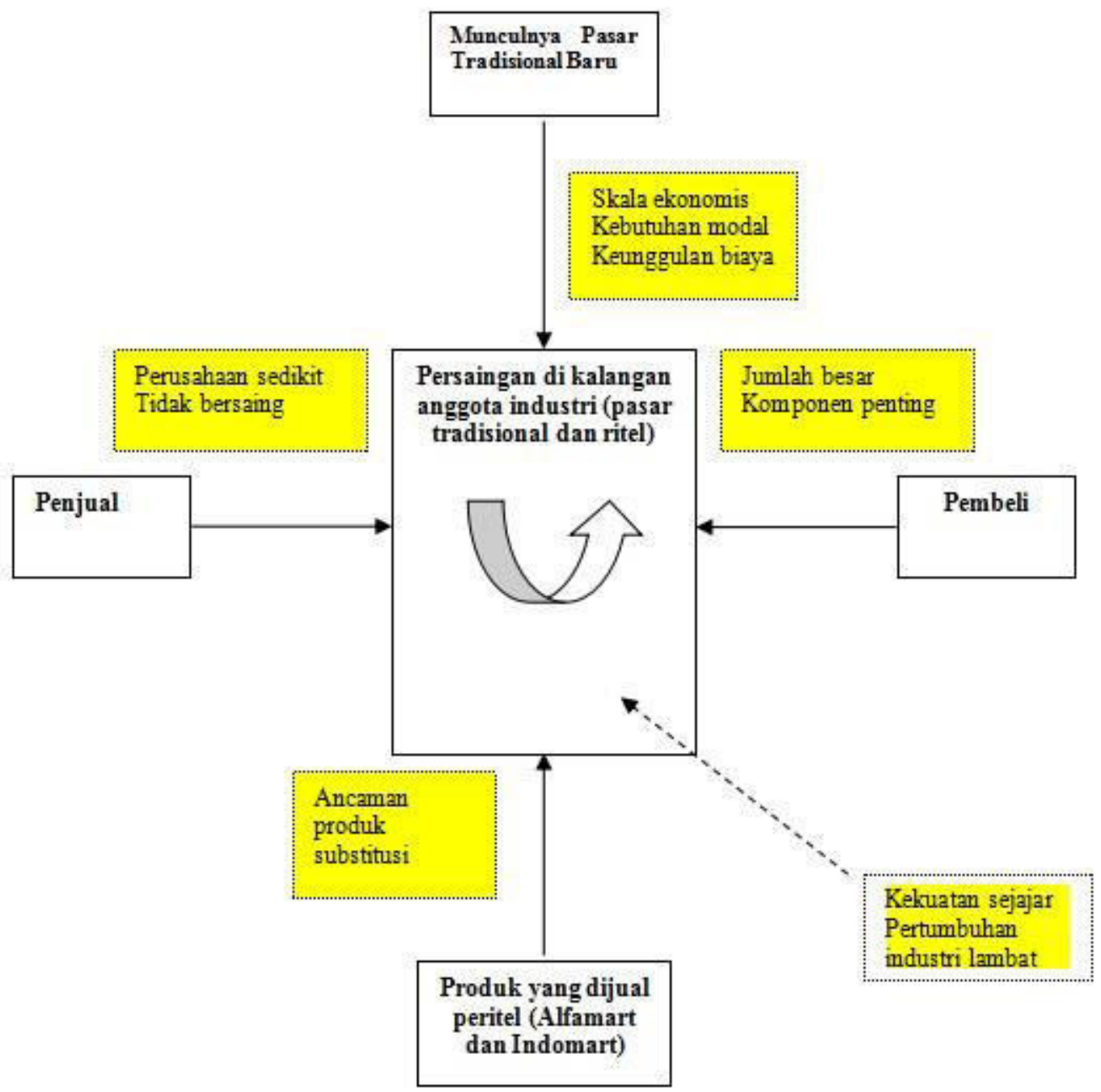

\section{Gambar 5.1. Kekuatan-kekuatan yang Mempengaruhi Persaingan Industri}

\subsection{Kesimpulan}

a. Pedagang yang berada di pasar festival lebih didominasi jenis kelamin laki-laki, usia produktif, berasal dari lulusan SMA/SMK, lebih banyak dari suku Jawa.

b. Waktu usaha sebagian besar pedagang masih di bawah satu tahun, dengan jumlah karyawan rata-rata $1-3$ tahun. Berdasarkan jenis komoditas usahanya, paling banyak para pedagang berjualan pakaian diikuti kuliner, diikuti berbagai jenis usaha lain dan asesories. Waktu usaha para pedagang rata-rata dibuka jam 06.00 pagi sampai 12.00 siang. Sedangkan menurut besar keuntungan per hari menjelaskan bahwa rata-rata pendapatan setiap usaha antara Rp 100.000,sampai Rp 400.000,-, dan selanjutnya pendapatan mereka di bawah Rp 100.000,- atau lebih dari Rp 550.000,- per harinya. Biaya sewa per bulan yang harus ditanggung pedagang berada di harga Rp 150.000,- sampai Rp 250.000,- per bulannya. Sedangkan lainnya lebih murah karena mendapat dispensasi dari manajemen. 
c. Pedagang merasa puas dengan beberapa fasilitas yang disediakan oleh manajemen pasar festival seperti: kondisi jalan yang baik, ketersediaan lahan parkir, kondisi persampahan, luas lapak yang memadai serta kondisi keamanan yang baik, sedangkan ketersediaan listrik dan air harus diperbaiki manajemen. Kriteria pedagang dalam memilih lokasi dikarenakan pasar festival dekat dengan sarana transportasi, biaya transportasi yang murah, jumlah pembeli yang banyak, lokasi tidak jauh dari rumah dan tersedianya kelengkapan peralatan. Sedangkan satu hal yang dikeluhkan pedagang karena banyak penjual dengan komoditas barang sama sehingga banyak pesaing.

\section{Daftar Pustaka}

Amin Widjaja Tunggal, 1994, Manajemen Stratejik, Edisi Pertama, Harvarindo, Jakarta Barat

Brigham, Daves, 2004, Intermediate Financial Management, $8^{\text {th }}$ Edition, South-Western, Thomson Corporation, United States of America

Collis, Montgomery, 2005, Corporate Strategy, $2^{\text {nd }}$ Edition, McGraw-Hill Companies, Inc., New York

Cooper \& Schindler, 2003, Business Research Method, $8^{\text {th }}$ Edition, McGraw-Hill Companies, Inc., New York

Hax \& Majluf, Strategic Management: An Integrative Perspective, Prentice-Hall., Englewood, New Jersey 07632

Heizer, Render, 2004, Operations Management, $7^{\text {th }}$ Edition, Pearson Education, Inc., Upper Saddle River, New Jersey Kim, Mauborgne, 2005, Blue Ocean Strategy, HBSP, Boston

McAfee, 2002, Competitive Solution: The Strategies's Toolkit, Princeton University Press

Octavianto, Fredy, 2005, Evaluasi Aplikasi Perencanaan Strategik Dalam Proses Perencanaan Program Investasi PT. Thames PAM Jaya, Program Pasca Sarjana Universitas Gadjah Mada: Tesis (tidak dipublikasikan)

Supriyono, 1993, Manajemen Strategi dan Kebijakan Bisnis, Edisi Pertama, BPFE, Yogyakarta

Porter (A), 1985, Competitive Advantage, Free Press, New York

Porter (B), 1980, Competitive Analysis, Free Press, New York

Supriyono, 1993, Manajemen Strategi dan Kebijakan Bisnis, Edisi Pertama, BPFE, Yogyakarta

Thompson, Strickland III, Gamble, 2005, Crafting and Executing Strategy, $14^{\text {th }}$ Edition, McGraw-Hill Companies, Inc., New York 
Yukl, 2006, Leadership in Organizations, $6^{\text {th }}$ Edition, Pearson Education, Inc., Upper Saddle River, New Jersey, 07458

Prilia Aristianti (2012), "Fenomena Pasar Modern dan Pasar Tradisional“, Analisis Jurnal

Noor Kholis, Alifah Ratnawati, Sitty Yuwalliatin (2011), "Pengembangan Pasar Tradisional Berbasis Perilaku Konsumen",

Dinamika Sosial Ekonomi Volume 7 Nomor 1 Edisi Mei 2011.

Wasisto (2012), "Pasar Tradisional versus Liberalisasi Bisnis Ritel di Indonesia”, JESP Vol.4, No. 2, 2012

Wicak (2010), "Keberadaan dan Perkembangan Pasar Kaget Rawajati Jakarta”, Program PascaSarjana, Undip, Semarang 